\title{
DOES CSR FOSTER INCLUSION AND DIVERSITY? AN EXPLORATORY STUDY OF IBERO-AMERICAN COUNTRIES
}

E. Suárez, L. Susaeta, J.M. Alcaraz, R. Perelló, C. Colón, I. Gutiérrez, R. Cunha, F. Leguizamón, S. Idrovo, N. Weisz, M. Correia, P. Apascaritei, José Ramón Pin 


\title{
DOES CSR FOSTER INCLUSION AND DIVERSITY? AN EXPLORATORY STUDY OF IBERO-AMERICAN COUNTRIES
}

\author{
E. Suárez¹, L. Susaeta², J.M. Alcaraz ${ }^{3}$, R. Perelló ${ }^{4}$, C. Colón ${ }^{5}$, I. Gutiérrez ${ }^{6}$, R. Cunha7, \\ F. Leguizamón ${ }^{8}$, S. Idrovo ${ }^{9}$, N. Weisz ${ }^{10}$, M. Correia ${ }^{11}$, P. Apascaritei ${ }^{12}$
}

José Ramón Pin ${ }^{13}$

\begin{abstract}
This paper aims to develop the theoretical concept of the social dimension of corporate social responsibility (CSR) through an empirical study focusing on the Ibero-American hospitality industry. We examined social initiatives in general and, in particular, diversity and social inclusion initiatives in four different Ibero-American countries: Argentina, Colombia, Mexico and Spain. We conducted 54 interviews involving 37 hotel chains. Our study revealed that a significant number of the actions carried out within the framework of the social dimension of CSR, and more specifically diversity and social inclusion, are in response to the concerns of certain people (human resources personnel or managers) rather than a perfectly shaped policy on the actions to be undertaken. Therefore, different actions have been undertaken in hotels that belong to the same chain, depending on the geographical area in which the hotels are operated. After having analyzed the actions undertaken by the hotels to promote diversity and social inclusion, we concluded that CSR actions are still in their early stages.
\end{abstract}

Keywords: Hospitality industry; Ibero-American; CSR; Diversity; Social inclusion; Social responsibility; Spain; Argentina; Mexico; Colombia

\footnotetext{
${ }^{1}$ Professor, ESIC

${ }^{2}$ Senior Lecturer, UCM

${ }^{3}$ Senior Lecturer, Murdoch University

${ }^{4}$ Senior Lecturer, Universidad Politécnica de Valencia

${ }^{5}$ Director, IEBEC

${ }^{6}$ Professor, Universidad de Las Américas

${ }^{7}$ Senior Lecturer, Universidade Nova de Lisboa

${ }^{8}$ Professor, INCAE

${ }^{9}$ Research Director, INALDE

${ }^{10}$ Professor, IAE

${ }^{11}$ Senior Lecturer, Universidade Nova de Lisboa

12 PHd, IESE

13 Professor of Managing People in Organizations and Business Ethics José Felipe Bertrán Chair of Governance and Leadership in Public Administration IRCO - International Research Center on Organizations, IESE
} 


\section{DOES CRS FOSTER INCLUSION AND DIVERSITY? AN EXPLORATORY STUDY OF IBERO-AMERICAN COUNTRIES}

\section{Introduction}

Ever since Elkington (1998) identified the "triple bottom line" (TBL) - social, economic and environmental - that companies should strive for in their operations, both scholars and practitioners have been concerned with adding this framework to their CSR or sustainability theories and practices. This TBL approach has gradually left behind the idea that the company should respond only to economic motivations, as defended by classic paradigms (Friedman, 1970; Fry et al., 1982; Navarro, 1988; Barry, 2000).

Within the context of our study on CSR in the hospitality industry, this triple perspective economic, social and environmental - is an appropriate conceptual framework for the implementation of coordinated, global and transversal CSR actions (T. Tyrrell, C. Morris Paris and V. Biaett, 2012).

However, the data gathered in our fieldwork revealed a lack of balanced outcomes in the triple bottom line of CSR. Additionally, while studies have recently been carried out in the hospitality industry in relation to the environmental dimension of CSR (Flammer, 2013; Geerts, 2014), financial performance (Kang, Lee and Huh, 2010) and the capital market (Orlitzky, Schmidt and Rynes, 2003; Becchetti, Ciciretti, Hasan and Kobeissi, 2012), there are fewer studies focusing specifically on the social dimension and especially on social inclusion and diversity (De Grosbois, 2012).

Therefore, this study aims to give robustness to the theoretical concept of "social CSR" and provide empirical data about how it is being implemented, especially in the case of diversity and social inclusion initiatives in the hospitality industry. The study also aims to provide a cross-cultural perspective given that we conducted our fieldwork in four different IberoAmerican countries: Argentina, Colombia, Mexico and Spain. Another motivation for our research is that the number of empirical studies in this geographical area is very limited. Finally, the tourism and hospitality industry plays an important role in the generation of employment and economic development in these four countries. It should be emphasized that employment is key to economic indicators and is one of the most important strategies for social inclusion (Lister, 2000; Lysaght, 2012).

\section{Dimensions of CSR Identified in the Literature}

The concept of CSR in the hospitality industry has attracted increasingly more attention in the past decade (J.L. Holcomb, R.S. Upchurch and F. Okumus, 2007; Jones, Hillier and Comfort, 2014). Although defined in different ways (Margolis and Walsh, 2003; Campbell, 2007), the 
concept of CSR involves the adoption of good and transparent business practices, while also taking into account environmental and social outcomes.

Porter and Kramer (2006) and Haugh and Talwar (2010) argue that the implementation of a coherently designed CSR strategy requires that three pillars (economic, social and environmental) be provided for and later studies (Porter and Kramer, 2011) stress the need for the creation of shared value.

The literature offers several interpretations of CSR and includes different dimensions for the analysis of this concept. A good attempt at such analysis is made in a paper published by the European Commission, which distinguishes between the internal dimension and the external dimension of CSR (COM 366, 2001). The internal dimension comprises socially responsible practices affecting investments in human capital, health and safety, and managing change. Additionally, it includes environmentally responsible practices relating to the management of natural resources used in production. The external dimension comprises relations with the local community, business partners and suppliers, customers, public authorities and NGOs representing local communities, as well as the environment (COM 366, 2001).

According to Dahlsrud (2008), CSR includes five dimensions: 1) environmental; 2) stakeholders; 3) economic; 4) voluntariness and 5) social. These dimensions were reflected in the definition of CSR provided by the European Commission: "the responsibility of enterprises for their impacts on society." In particular, the Commission explains that "enterprises should have in place a process to integrate social, environmental, ethical, human rights and consumer concerns into their business operations and core strategy in close collaboration with their stakeholders" (European Commission, 2011).

The environmental dimension relates to environmental concerns in business operations; the stakeholder dimension involves how organizations interact with their employees, suppliers, customers and communities; the economic dimension encompasses socioeconomic or financial aspects, describing CSR in terms of a business operation; the voluntariness dimension comprises actions not prescribed by law and it is based on ethical values; and, finally, the social dimension refers to the relationship between business and society, considering the full scope of businesses' impact on communities (Dahlsrud, 2008).

Although Dahlsrud's contribution should be acknowledged because it offers a comprehensive list of what CSR includes and it attempts to measure the weight of each of the five dimensions, we find the outline of the five dimensions proposed to be confusing. From our point of view, both the stakeholder dimension and the voluntariness dimension are encompassed within the other dimensions: social (mainly communities, employees and NGOs), economic (mainly shareholders) and environmental.

\section{Social Dimension of CSR, Diversity and Social Inclusion}

According to Haugh and Talwar (2010), the social dimension of the sustainability of CSR includes the humanitarian context of business and relates to issues of poverty and income inequality, disease, access to health care, clean water and sanitation as well as inclusion through education, especially for females and people who have had no opportunities to study. This dimension also includes the broader problems associated with the impact of globalization on economic development. 
For the social dimension of CSR, it is vital to develop strong and mutually beneficial relationships with the community. One way in which the hospitality industry is involved in communities is through proactive social inclusion projects and diversity management. The promotion of diversity and inclusion is an essential component of the social dimension of CSR (Palthe, 2013).

Social inclusion has always been a concern of the public sector. However, with the advent of CSR, companies in the private sector began to be considered as having an important role in reducing social inequalities and poverty in the communities in which they are located (Newell and Frynas, 2007; World Business Council for Sustainable Development and SNV, 2010).

Along these lines, Werner (2009) argues that CSR initiatives enable businesses to maximize positive effects on the poor and minimize negative economic externalities. In this regard, Petrovici (2013) argues that CSR practices do not replace what governments should do to promote social development and inclusion in countries with high rates of poverty and inequality but they can increase the integration of job markets and promote the social inclusion of vulnerable groups.

Diversity consists of a range of characteristics, such as gender, race, disability, religion, belief, sexual orientation and age, as well as personal characteristics, such as work style, social class, personality and culture (M. Emmott and D. Worman, 2008; Goodman, 2013). Accordingly, diversity is a common feature in the hospitality industry and is even more important in our study since several of the countries analyzed (mainly Argentina, Colombia and Mexico) have a rich mixture of ethnic groups and cultures, in addition to being societies with considerable social inequalities.

Chiappetta, Serotini, Caldeira, Martínez and Gomes (2011) believe that diversity has to do with practices that seek to include minorities who have been marginalized historically in terms of the workplace variable.

Social inclusion is about giving opportunities to disadvantaged people. In the words of the World Bank, "Social inclusion is the process of improving the ability, opportunity and dignity of people, disadvantaged on the basis of their identity, to take part in society" (World Bank, 2013).

Corporate inclusion initiatives seek both to provide training and employment opportunities and to educate ethnic minorities, women without formal education, physically challenged individuals and, in general, all disadvantaged people, in practices related to health, etc., in order to avoid the risk of social exclusion. For this reason, some studies have addressed diversity and social inclusion together (Goodman, 2013), since they are closely related concepts intended to prevent discrimination and at times the line that separates them is very thin (Roberson, 2006). In fact, in some of the hotels' CSR reports, the two concepts are addressed jointly. For example, the report drafted by the Marriott hotel chain includes "global diversity and inclusion" in the same paragraph.

Effective CSR activities aimed at diversity management and inclusion in Latin America are of even greater significance since companies are the drivers of the social, economic and political change required by these countries (WBCSD and SNV, 2010). In this regard, the hospitality industry has a great deal to contribute since, according to UNWTO (World Tourism Organization, 2014), its performance is key to development, prosperity and well-being. 


\section{Research Questions}

This study aimed to address the following research questions:

Research question 1: What CSR initiatives (mainly of a social dimension) are being carried out in the hospitality industry in the four countries studied?

Research question 2: What are the motives for and objectives of these social actions? Are they proactive or reactive?

Research question 3: Are diversity and social inclusion promoted through CSR in the hotel industry in Latin America? What impact do the social initiatives have on the local community?

\section{Conceptual Model}

In order to answer the research questions mentioned above, we used an adaptation of the Global Reporting Initiative (GRI) framework. GRI is an organization in the sustainability area that encourages organizations to use sustainability reports on social, environmental and economic dimensions. Our study focuses solely on three issues relating to the social performance of CSR. Social performance includes interactions between an organization and its community. The subcategories that GRI considers in the social dimension are: 1) labor practices and decent work; 2) human rights; 3) society; and 4) product responsibility. Our study did not take into account the paragraph on product responsibility included in the GRI framework's section on social performance, since it was unrelated to the object of our study.

Using Atlas.ti, we divided the social initiatives into three of the subcategories of the GRI framework's social dimension - 1) labor practices and decent work; 2) human rights and 3) society (Figure 1) - and then analyzed the initiatives. Additionally, as in the case of the European Commission's classification, our model distinguishes between the internal dimension of CSR (labor practices and decent work) and the external dimension (society). In our view, the human rights subcategory of the GRI framework can form part of both the internal and external dimensions, depending on the practices in question. Figure 1 presents the framework guiding our empirical study.

Our analysis reviewed all the CSR social initiatives discussed in the interviews and then identified those related to diversity and social inclusion. Our model moves from general to specific considerations. In other words, it is deductive, first analyzing all CSR practices carried out in hotels and the importance given to the social and environmental dimensions and then focusing on the social dimension and, within this dimension, diversity and social inclusion. 


\section{Figure 1}

A framework for evaluating CSR's contribution to social inclusion and diversity

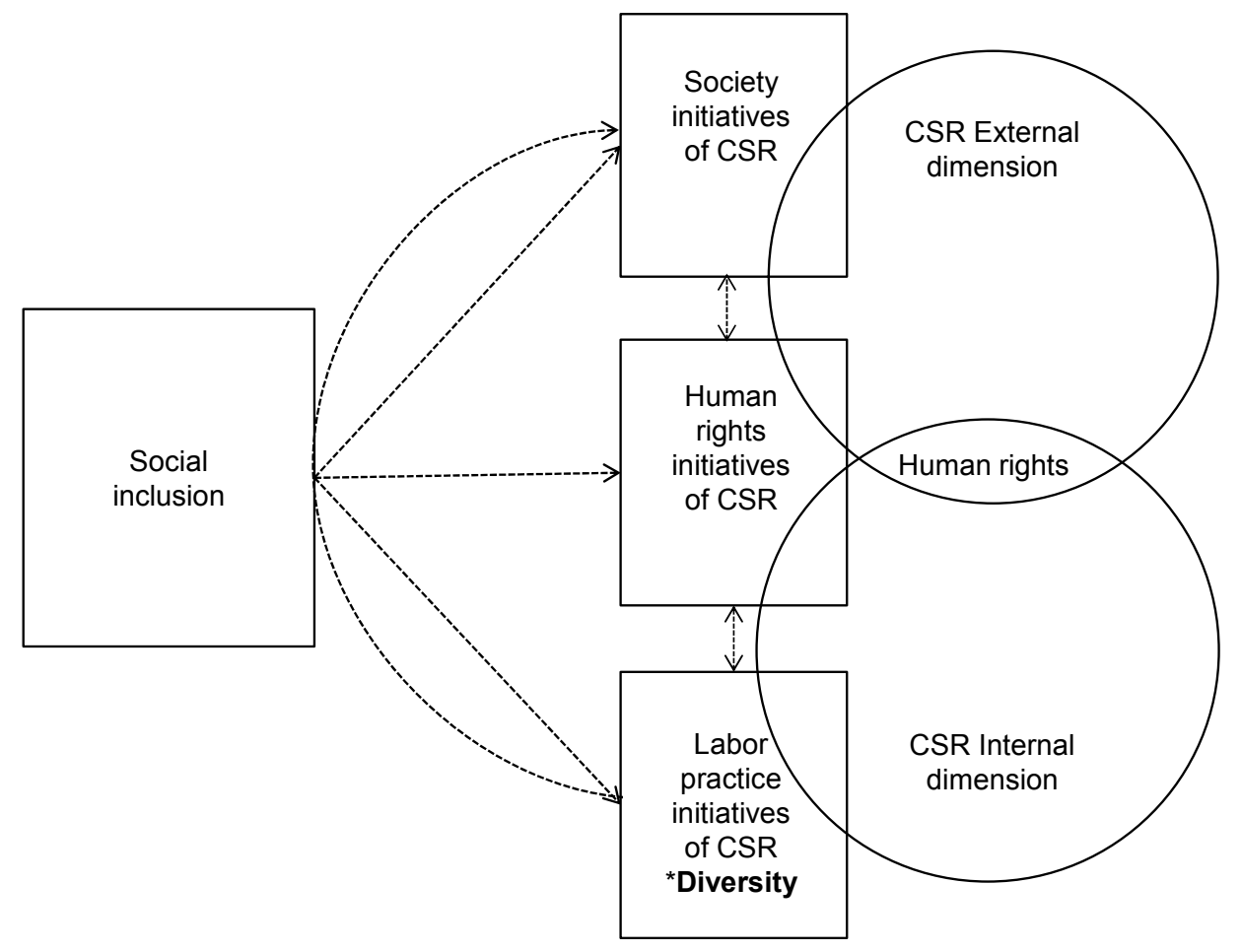

\section{Research Design, Method and Data}

\section{Selection of Hotel Chains and Gathering of Data}

The CSR programs carried out by large hotel groups have a substantial impact on surrounding communities worldwide. For this reason, 70\% of the hotels chosen are part of large hotel chains (Table 1). The remaining 30\% of the hotels whose managers were interviewed are smaller in scale, enabling us to analyze social initiatives implemented in local hotels.

We carried out our fieldwork in hotel chains in Ibero-America (Argentina, Colombia, Mexico and Spain). We chose these areas for the following reasons: firstly, the growth of the hotel industry in these countries acquired an enormous dimension; secondly, we included Spain along with the other countries due to the traditionally significant investment made by Spanish multinationals in this geographical area; thirdly, many of the areas in which hotels are prominent promote social initiatives and social inclusion.

\section{Interviews}

We interviewed mainly HR and CSR managers from recognized "champions" and leading companies (Table 1) with one or more of the following characteristics: companies certified by organizations such as 1) GRI, the institution that created the first worldwide standard of indicators for the drafting of sustainability or CSR reports taking into account economic, social and environmental performance, 2) EarthCheck, a certifying agent in the sustainability field, or 3) FTSE4Good, an indicator recognized worldwide by investors who seek to identify companies with responsible business practices; companies identified as "active" in the United Nations 
Global Compact directory; and recipients of national or international awards recognizing their social and environmental commitment. Additionally, we focused on hotels belonging to hotel groups that are members of the International Tourism Partnership, an organization meant to bring "together the world's leading international hotel companies to provide a voice for environmental and social responsibility in the industry."

The research team that carried out this project is made up of four scholars from the four IberoAmerican countries mentioned above. Over a one-year period (from January 2012 to January 2013), the team conducted 54 interviews. From February 2013 to February 2014, we supplemented certain data from the interviews and reviewed reports on corporate responsibility or sustainability drafted by the large hotel chains that took part in the study. The interviews took between 90 and 120 minutes and involved 37 hotel channels. More specifically, 11 interviews were conducted in Argentina, 10 in Colombia, 6 in Spain and 7 in Mexico. Table 1 shows the profiles of the people interviewed.

We followed a semi-structured interview protocol that began with general questions about how the concept of CSR is understood and about the trends in the hospitality industry. We also asked questions concerning the interviewee's beliefs about the importance of CSR in the company's strategy. Lastly, we asked different questions about the main initiatives relating to inclusion, diversity, social responsibility and corporate volunteering. We asked about the objectives of, motives for and outcomes of these initiatives.

We organized the interviews around the following core topics:

1. What does your company do in the CSR domain? This line of questioning was meant to determine the extent to which hotels undertook coordinated CSR actions and how developed these actions were. We also wanted to analyze the weight of the social dimension of CSR actions.

2. What does your company do for the purpose of social involvement? Through the second question topic, we aimed to determine the specific social initiatives that were carried out and the reasons behind them, as well as whether the actions were proactive or reactive.

3. To what extent are employees committed to social initiatives? We wanted to find out whether, in addition to donations and philanthropic opportunities, the hotels had carried initiatives that involved staff members to a greater extent.

4. How much do managers support and become involved in the social dimension of CSR? Questions related to this topic were meant to determine whether the degree to which managers were convinced of the need for social initiatives had an influence on the initiatives' success.

The researchers analyzed the data using inductive content analysis with an emphasis on the content of the discussion. As a unit of analysis, the research team chose some words or sentences related to the study topic.

We created a single file containing the 54 interviews conducted in all four countries. We recorded, transcribed and analyzed the interviews in Atlas.ti 6.0, a computer program used for qualitative analysis. In order to have additional data, we also analyzed the CSR reports drafted by the hotels whose managers were interviewed using Atlas.ti. 


\section{Table 1}

Interviewed hotel managers

\begin{tabular}{|c|c|c|c|}
\hline HR profile & CSR profile & Ownership & $\begin{array}{l}\text { Headquarters } \\
\text { (origin) }\end{array}$ \\
\hline \multicolumn{4}{|l|}{ MEXICO } \\
\hline & General manager & Independent hotel & Mexico \\
\hline Human resources manager & Quality manager & Multinational chain & Spain \\
\hline Human resources manager & Coordinator of certifications & Independent hotel & Mexico \\
\hline Head of training & $\begin{array}{l}\text { Quality assurance and business } \\
\text { sustainability manager }\end{array}$ & Multinational chain & Spain \\
\hline \multirow[t]{3}{*}{ Human resources manager } & General comptroller & Independent hotel & Mexico \\
\hline & $\begin{array}{l}\text { Engineering and maintenance } \\
\text { manager }\end{array}$ & Multinational chain & Spain \\
\hline & General manager & Independent hotel & Mexico \\
\hline Human resources manager & Maintenance manager & Multinational chain & Spain \\
\hline Director of human resources & & Multinational chain & United States \\
\hline Head of education and training & & Multinational chain & United States \\
\hline Human resources manager & Social responsibility manager & Multinational chain & Mexico \\
\hline \multicolumn{4}{|l|}{ COLOMBIA } \\
\hline Human resources & Responsible sustainability & Multinational chain & United States \\
\hline \multirow{2}{*}{$\begin{array}{l}\text { Head of human resources } \\
\text { management }\end{array}$} & & Multinational chain & United States \\
\hline & General manager & Multinational chain & Spain \\
\hline Head of HR & & Multinational chain & United States \\
\hline HR manager & & Multinational chain & United States \\
\hline HR manager & & Multinational chain & United States \\
\hline HR manager & & Independent hotel & Colombia \\
\hline Head of HR & Director of the foundation & Multinational chain & United States \\
\hline \multicolumn{4}{|l|}{ ARGENTINA } \\
\hline Head of human resources & General manager & Multinational chain & Spain \\
\hline Human resources manager & Maintenance manager & Multinational chain & Spain \\
\hline Human resources manager & & Independent hotel & Argentina \\
\hline Human resources manager & Director of marketing, sales and CSR & Multinational chain & United States \\
\hline Human resources manager & & Independent hotel & Argentina \\
\hline $\begin{array}{l}\text { Human resources and CSR } \\
\text { manager }\end{array}$ & & Multinational Chain & Canada \\
\hline Human resources manager & & Independent hotel & Argentina \\
\hline Human resources manager & & Independent hotel & Argentina \\
\hline \multicolumn{4}{|l|}{ SPAIN } \\
\hline & CSR manager & Multinational chain & Spain \\
\hline \multirow[t]{2}{*}{ HR director } & $\begin{array}{l}\text { Senior vice-president, strategic } \\
\text { planning group/CSR manager }\end{array}$ & Multinational chain & Spain \\
\hline & Sustainability associate & Independent hotel & Spain \\
\hline $\begin{array}{l}\text { Director of HR and } \\
\text { sustainability }\end{array}$ & & Multinational chain & United States \\
\hline HR director & General manager & Multinational chain & Spain \\
\hline Associate HR director & Housekeeping and CSR supervisor & Multinational chain & United States \\
\hline \multirow[t]{2}{*}{ HR director } & & Independent hotel & Spain \\
\hline & $\begin{array}{l}\text { Regional director of operational } \\
\text { innovation for Spain and Portugal }\end{array}$ & Multinational chain & United States \\
\hline Vice-president HR & Vice-president, corporate responsibility & Multinational chain & Spain \\
\hline HR director & & Multinational chain & United States \\
\hline Director of HR and CSR & & Multinational chain & Spain \\
\hline $\begin{array}{l}\text { Director of HR and } \\
\text { sustainability }\end{array}$ & & Multinational chain & United States \\
\hline
\end{tabular}




\section{Findings}

\section{Research question 1: What CSR initiatives (mainly of a social dimension) are being carried out in the hospitality industry in the four countries studied?}

In the area of environmental sustainability, the management was highly committed in almost all the big chains, and there are measurements, indicators and targets for executives and middle management. The same is not true in the case of social initiatives, which are implemented in a more disorderly manner. Normally there are no indicators relating to the social dimension but most hotels refer to the information published in their CSR report. Measurements relating to social actions were scarce. However, we found that one Spanish hotel chain has a management system called the Solidarity index, enabling it to identify the local projects and organizations whose field of work, objectives and needs are in line with its social action strategy. The social actions were found to be more coordinated in Spain than in the other countries studied.

Some of the practices included in the social dimension of CSR are actually human resource or labor relations practices that are mandatory. Complying with the law in force is the minimum threshold of CSR. Certain independent hotels located in undeveloped areas claimed to be socially responsible simply because they complied with the minimum requirements under labor law. This was especially true in Mexico:

"I take full responsibility for an employee when hiring him or her, I give the employee a decent wage, a decent place to eat, and what he or she needs to work. I don't give employees double shifts and I hire employees for a one-year period rather than just four months. Here contracts are usually for four months."

It should be pointed out that this hotel is located in Cancún and, from the standpoint of the person being interviewed, one of the greatest challenges is to improve the political and social environment.

"Living in Cancún is already a challenge [...] We have had very poor governments. 70\% of our municipal presidents have been in jail [...] They only govern for their own benefit and for the benefit of the business people who pay them off. Living in Cancún gives rise to a considerable social conflict. People work 12 hours a day [...] Often the hotels in the area ask them to work double shifts to save money [...] We are the state with the highest suicide rate [...] In the vast majority of the hotels, people work under so-called solidarity contracts: you work only four months a year and, in the remaining months, you sign a contract in which the hotel commits to giving you work again when the hotel occupancy rises."

However, curiously enough, the hotels that do not make major investments in social actions (especially in Mexico and Colombia) do make considerable efforts relating to environmental issues and protecting the culture or indigenous species in the region in which they are located. This may be due to the fact that CSR is more oriented to the customer than to the development of the communities in which the hotels are located.

The social initiatives carried out by the hotels whose managers were interviewed are classified in Table 2. This table includes both diversity and social inclusion initiatives related to the three subcategories of the proposed model: labor practices, human rights and society. However, it can 
be argued that the hotels located in areas that are poorly developed economically could still do more. The head of human resources of a hotel in Mexico belonging to a multinational chain agreed:

"I believe that we can still contribute more to supporting the community, that is to say, the area below the hotel is quite deprived and perhaps we could take advantage of the opportunities to carry out more social initiatives there."

\section{Table 2}

Examples of social initiatives in interviews and public documents: labor practices, human rights and society

\begin{tabular}{|c|c|}
\hline \multicolumn{2}{|r|}{ SPAIN } \\
\hline $\begin{array}{l}\text { Labor practices } \\
\text { and decent work }\end{array}$ & 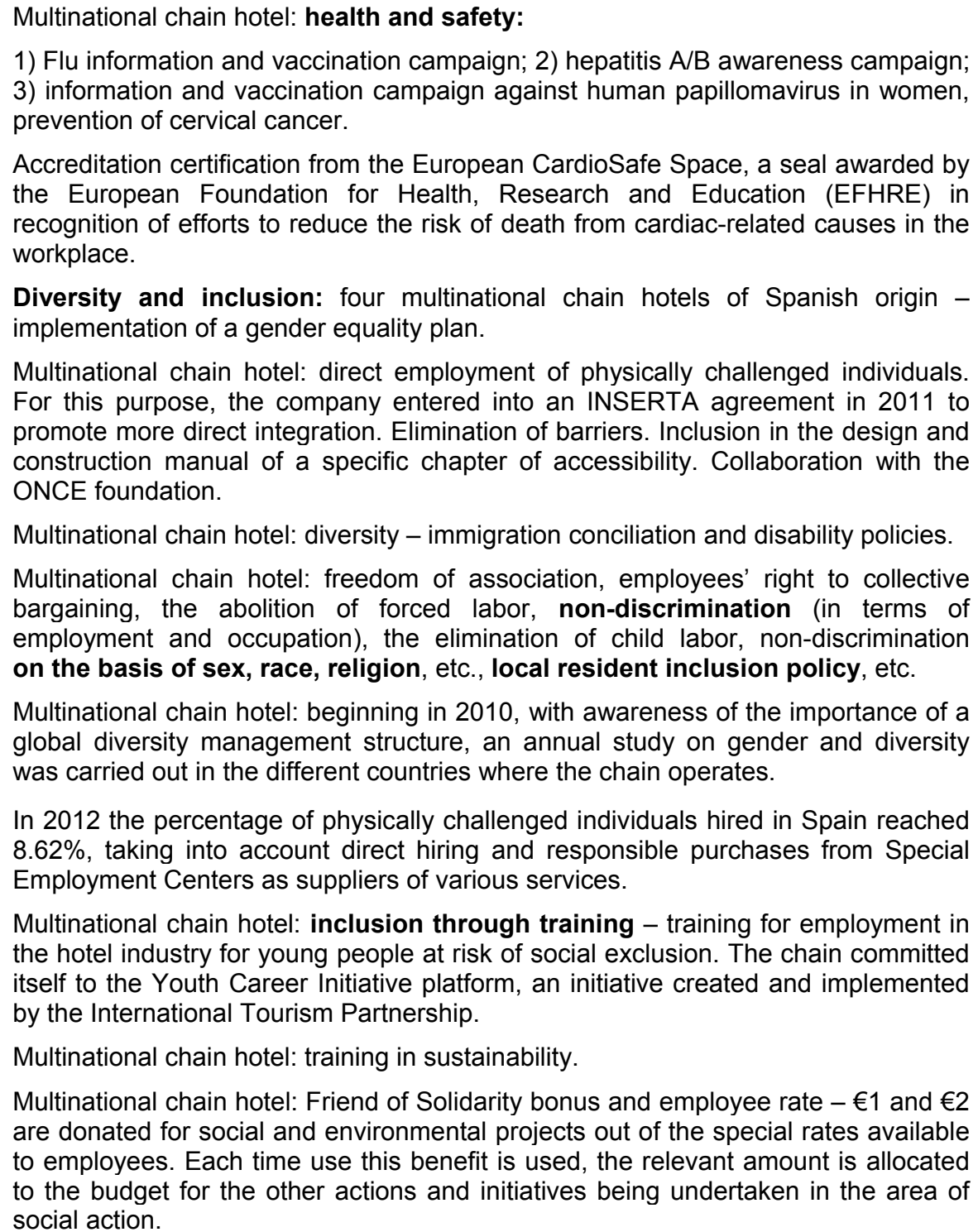 \\
\hline
\end{tabular}




\section{Table 2 (continued)}

\begin{tabular}{|c|c|}
\hline & SPAIN \\
\hline $\begin{array}{l}\text { Human rights } \\
\text { and donations }\end{array}$ & $\begin{array}{l}\text { Common findings in four multinational chain hotels: } \\
\text { Children's rights: adherence to the Code of Conduct for the Protection of Children } \\
\text { From Sexual Exploitation in Travel and Tourism of ECPAT (End Child Prostitution, } \\
\text { Child Pornography and Trafficking in Children for Sexual Purposes). Inclusion of } \\
\text { ECPAT commitments in the company's sustainability policies. } \\
\text { Adherence to the United Nations Global Compact (http://www.unglobalcompact.org). } \\
\text { Commitment to its } 10 \text { principles. } \\
\text { Multinational chain hotel: the social commitment to children was strengthened } \\
\text { through the signing of the strategic alliance with UNICEF Spain to collaborate } \\
\text { to achieve the objectives of UNICEF (the United Nations Children's Fund) for } \\
\text { education, child protection and the fight against sexual exploitation and the } \\
\text { trafficking of children. } \\
\text { Multinational chain hotel: the Global Code of Ethics for Tourism was approved in } \\
1999 \text { by the World Tourism Organization of the United Nations. It includes } \\
10 \text { principles designed to guide the main actors of tourism development to } \\
\text { maximize the benefits of the industry and minimize the impact on the environment, } \\
\text { cultural heritage and local communities (http://www.unwto.org). } \\
\text { Multinational chain hotel: donation of free rooms to families of hospitalized children, } \\
\text { a replica of the international Menudos Corazones (Little Hearts) program (Spain) } \\
\text { with the involvement of employees. } \\
\text { Multinational chain hotel: donations to the Barceló Foundation. Participant in } \\
\text { several projects in both developing countries and Spain. } \\
\text { Multinational chain hotel: donations to UNICEF for training programs in developing } \\
\text { countries. } \\
\text { Multinational chain hotel: donations to the Campaner Foundation, founded by a } \\
\text { receptionist of the RIU hotel chain, to combat the disease noma affecting children } \\
\text { in Africa. }\end{array}$ \\
\hline Society & $\begin{array}{l}\text { Multinational chain hotel: commitment to the conservation of the tangible and } \\
\text { intangible cultural heritage of the communities in which it operates. Fully involved at } \\
\text { the local level, integrating the indigenous cultural, gastronomic and artistic } \\
\text { elements of each region. } \\
\text { Social inclusion: indirect job placement. The group's shopping area promotes the } \\
\text { purchase of products and services from Special Employment Centers to enhance } \\
\text { indirect integration. } \\
\text { The initiative that accounts for } 79 \% \text { of the total funds raised is the so-called Check- } \\
\text { in Solidarity initiative whereby customers are invited to donate } € 1 \text { to UNICEF for the } \\
\text { first night of their stay at the hotel. } \\
\text { Multinational chain hotel: the AMI program, aimed at improving the health of those } \\
\text { most in need, the volunteer program (which manages visits by health personnel, } \\
\text { etc., and the economic contributions received) and the economic development } \\
\text { program, projects aimed at providing decent housing and, in general, attention to } \\
\text { the most needy in developing countries. } \\
\text { The project ALISOL (Food Solidarity), whose main purpose is to provide food aid to } \\
\text { people of Mallorca in situations of real need. } \\
\text { Multinational hotel chain: corporate volunteering - employees help free of charge } \\
\text { by providing expert advice for the purpose of opening a hotel school in Ethiopia } \\
\text { (inclusion through training). } \\
\text { Collaboration with the NGO Equipo Cooperante (Volunteer Team). Another } \\
\text { example of corporate volunteering is that employees of the hotels in Salamanca } \\
\text { (Spain) designed and taught a distance learning course entitled "Customer Service. } \\
\text { A Real Experience With NH Hotel Group" to hotel and catering students of the } \\
\text { National University of Villarrica (Paraguay), to provide training that would enable } \\
\text { them to develop successful hotel projects in their country. }\end{array}$ \\
\hline
\end{tabular}




\section{Table 2 (continued)}

\begin{tabular}{|c|c|}
\hline \multicolumn{2}{|r|}{ ARGENTINA } \\
\hline $\begin{array}{l}\text { Labor practices and } \\
\text { decent work }\end{array}$ & $\begin{array}{l}\text { Multinational chain hotel: the charity Obra del Padre Mario (González Catán, } \\
\text { Buenos Aires, Argentina). } \\
\text { Collaboration in a training project to facilitate the integration of young people at } \\
\text { risk of social exclusion in the labor market. In } 2010 \text {, two young people from the } \\
\text { Obra del Padre Mario charity did internships in the hotel. } \\
\text { Independent hotel: any employee from any department can leave their usual work } \\
\text { twice a month to work with the sustainability team. Training: every two months, the } \\
\text { hotel managers participate in classes on sustainability. } \\
\text { Independent hotel: inclusion through training and the generation of local } \\
\text { employment. The staff selection process initiated at the time the hotel was } \\
\text { inaugurated sought to hire as many people as possible from the local Salta } \\
\text { community. About } 300 \text { people were trained and } 120 \text { were eventually hired to work } \\
\text { in the hotel. } \\
\text { Independent hotel: inclusion through training. A program called Fines (Purposes) } \\
\text { was carried out in collaboration with the Ministry of Education. It enabled primary } \\
\text { and secondary school classes to be held within the hotel, which benefited not only } \\
\text { the employees but also the community outside. } \\
\text { Inclusion through employment: there is a "young professionals" project for } \\
\text { recruiting young people without prior experience to train them and give them tools. } \\
\text { Independent hotel: inclusion through employment. A resident of the community } \\
\text { was trained and hired to do the laundry with biodegradable products. } \\
\text { Multinational chain hotel: it has been aiding a hotel in the Villa } 21 \text { shantytown area } \\
\text { of Buenos Aires for } 10 \text { years. }\end{array}$ \\
\hline $\begin{array}{l}\text { Human rights } \\
\text { and donations }\end{array}$ & $\begin{array}{l}\text { Multinational chain hotel: donations for cancer research. The hotel sponsors an } \\
\text { annual walk to sponsor a group of children who have had cancer. } \\
\text { Independent hotel: donations to the foundation Un Techo Para Mi País (A Roof for } \\
\text { My Country). } \\
\text { Multinational chain hotel: donations to UNICEF. }\end{array}$ \\
\hline Society & $\begin{array}{l}\text { Multinational chain hotel: "we support the neediest." Innovative training program } \\
\text { and consulting services for young people (inclusion) and celebration of cultural } \\
\text { diversity wherever hotels are located. } \\
\text { Multinational chain hotel: 1) collaboration with the Fundación Crear Vale la Pena } \\
\text { (Creating Is Worthwhile Foundation), which aims to achieve the social inclusion of } \\
\text { low-income young people through artistic and community activities; 2) } \\
\text { commitment to the community and inclusion: the hotel worked with the Fundación } \\
\text { Escolares (Scholars Foundation), a non-profit organization whose mission is to } \\
\text { contribute to the integral development of students in isolated rural schools of the } \\
\text { country and to eradicate drop-outs, and with the Faidela Foundation from Córdoba } \\
\text { province, a non-profit institution whose mission is to improve the living conditions of } \\
\text { socially excluded senior citizens. } \\
\text { Independent hotel: health-related training was supplied to four vegetable suppliers. } \\
\text { Independent hotel: training for inclusion - a program called Fines (Purposes) was } \\
\text { carried out in collaboration with the Ministry of Education. It enabled primary and } \\
\text { secondary school classes to be held within the hotel and was also aimed at the } \\
\text { community outside. } \\
\text { Independent hotel: inclusion of local suppliers - purchase of vegetables from } \\
\text { neighbors' gardens. } \\
\text { Multinational chain hotel: training for inclusion - training a group of single } \\
\text { mothers to wash, iron, write a CV, express themselves orally, etc., aimed at gaining } \\
\text { employment. }\end{array}$ \\
\hline
\end{tabular}




\section{Table 2 (continued)}

\begin{tabular}{|c|c|}
\hline \multicolumn{2}{|r|}{ COLOMBIA } \\
\hline $\begin{array}{l}\text { Labor practices and } \\
\text { decent work }\end{array}$ & $\begin{array}{l}\text { Independent hotel (which belongs to a builder): inclusion favored through training } \\
\text { and employment - Estudiar Para Construir (Study to Build) program, an education } \\
\text { program for hotel employees, } 90 \% \text { of whom had only a basic level of education. } \\
\text { The purpose is for employees to create their "life project." Some of the benefits of } \\
\text { this program are: } \\
\text { - Grants: } 80 \% \text { coverage of tuition fees } \\
\text { - } 100 \% \text { of food costs subsidized } \\
\text { - } 100 \% \text { of transportation costs subsidized } \\
\text { - Academic monitoring and permanent advice through teaching managers } \\
\text { - Workshops and activities aimed at strengthening each life project } \\
\text { - Academic access to an educational institution for adults with a proven track } \\
\text { record and credibility in the market } \\
\text { - Possibility of obtaining primary and secondary school diplomas, backed by the } \\
\text { district secretary of education } \\
\text { - Direct recruitment of staff for both the hotel and construction } \\
\text { Independent hotel: health and safety - agreement with the Liga Colombiana } \\
\text { Contra el Cáncer (Colombian League Against Cancer) to apply human } \\
\text { papillomavirus vaccines to collaborators and their family members with a certain } \\
\text { degree of consanguinity. } \\
\text { Independent hotel: health and safety - health week program. A body care } \\
\text { campaign was carried out for employees and their families. } \\
\text { Independent hotel: inclusion through employment - the hotel provides job } \\
\text { opportunities for physically challenged individuals and has agreements with FIDES } \\
\text { (Foundation for Research and Development of Special Education) and the Canes } \\
\text { Foundation. } \\
\text { Independent hotel: inclusion through employment - the program Estrellas del } \\
\text { Progreso (Stars of Progress) is designed to work with communities outside. In the } \\
\text { interview, the interviewee mentioned a specific case in the community of } \\
\text { Manzanillo (Cartagena), where a chain hotel is located. People in the community } \\
\text { are given employment training, which helps to develop the surrounding community. } \\
\text { Some of the jobs are as housekeepers and maintenance workers. } \\
\text { Independent hotel: inclusion of physically challenged individuals - alliance with } \\
\text { the foundation RECA (Employment With Support Network Colombia) for the } \\
\text { employment of physically challenged individuals. }\end{array}$ \\
\hline $\begin{array}{l}\text { Human rights and } \\
\text { donations }\end{array}$ & $\begin{array}{l}\text { Donations and alliances: } \\
\text { Independent hotel: it works with UNICEF against the sexual exploitation of children. } \\
\text { Multinational hotel chain: works with FANA (Foundation to Help Abandoned } \\
\text { Children), with a clinic to look after raped and abused children and with the charity } \\
\text { Un Techo Para Mi País (A Roof for My Country). } \\
\text { The AR Foundation, whose mission is to contribute to the economic and social } \\
\text { development of Colombia. } \\
\text { Agreements: } \\
\text { Multinational chain hotel: children's rights - adherence to the Code of Conduct for } \\
\text { the Protection of Children From Sexual Exploitation in Travel and Tourism of } \\
\text { ECPAT. }\end{array}$ \\
\hline
\end{tabular}




\section{Table 2 (continued)}

\section{COLOMBIA}

In 2010, the Barceló Foundation funded a project to build a nursery in Potrero Grande (Colombia) in collaboration with the foundation Manos Providentes (Provident Hands).

Hotel belonging to the Colombian group: the AR Foundation is responsible for leading all the projects, which primarily involve social responsibility. Among the projects: inclusion through training and employment - Bibliotecas Para Educarte (Libraries to Educate), a model of working with the community, where professionals provide ongoing aid to children, teenagers and adults, based on the promotion of reading, community development, the good use of free time and a healthy life.

- The model encourages social transformation through the monthly programming of educational, cultural, recreational and sporting activities that respond to the needs of the community.

- Training processes: non-formal training, geared to respond to the needs of the community, promote the development of social skills and improve their quality of life.

Society Independent hotel: inclusion through local suppliers - Patios Productivos (Productive Courtyards), a planned project in partnership with the Clinton Foundation. This initiative seeks to ensure that the region's people grow products in their courtyard that may be purchased by the hotel.

- Cooperation with the program Operación Sonrisa (Operation Smile). This hosts all doctors who travel to perform cleft lip surgery on low-income minors in cities where the chain has a hotel.

- Menú Para el Alma (Menu for the Soul) program - the hotel chef hosts a lunch one Sunday every month and the money raised helps the neediest families in the area.

- Inclusion of victims of violence program - the Trabajemos Unidos (Let's Work Together) job match program, operating in Manizales, seeks to find employment for mothers who are the head of the household but who are displaced and are victims of violence.

Multinational chain hotel: the chain's own foundation, called Amiguitos Royal (Royal Friends), works with low-income minors and focuses particularly on fighting against malnutrition. 


\section{Table 2 (continued)}

\section{MEXICO}

\section{Training:}

Multinational chain hotel: conference to promote awareness of hotel staff in the fight against human trafficking.

Multinational chain hotel: social inclusion through employment - 10 students graduated after receiving theoretical and practical training. Six of them were hired in different hotels in the chain.

Independent hotel: inclusion through training - specific academic regulation program, due to the fact that the hotel had a high number of employees who had not even completed secondary school.

Independent hotel: inclusion through housing - aid to employees to build their houses.

Independent hotel: inclusion through health and safety initiative - "We now have a pilot project, El Plato del Buen Comer (Plate of Good Food), for the improvement of nutrition. This year our efforts were fully aimed at balanced nutrition. Unfortunately Yucatán is number one in obesity, high blood pressure and diabetes, which is why we took on this project."

Labor practices and decent work
Inclusion: training initiatives and employment - "We prioritize the incorporation of local community residents into the workforce, thus promoting vocational training. Residents were then trained to be waiters, cooks, cleaning staff, gardeners, etc., through a committed hotel training process aimed at achieving excellence, without losing the values and principles of Mayan culture." (http://www.haciendasmundomaya.com/nuestra-historia/historia)

Multinational chain hotel: corporate volunteering actions - employees of the hotel chain give handicraft workshops for physically challenged children and teenagers or those who have autism or cancer, in cooperation with a foundation.

Social inclusion through employment: $85 \%$ of the employees are from the area (multinational chain hotel).

"In the low season, we have hired employees for four extra months, rather than dismissing them. The government covers two months of pay through ICAPET [Work Training and Productivity Institute] and the hotel contributes two additional months for a given number of employees." (Independent hotel)

\section{Equality}

"We hire all kinds of people without regard to sex, age or religion. All people have the opportunity to work here in the company." (Multinational chain hotel)

"Among our employees we have illiterate people and physically challenged individuals. Everyone has a chance." (Independent hotel) 


\section{Table 2 (continued)}

\begin{tabular}{|l|l|}
\hline \multicolumn{1}{|c|}{ MEXICO } \\
\hline & $\begin{array}{l}\text { Independent hotel: donations to the Fundación Haciendas del Mundo Maya } \\
\text { (Haciendas of the Mayan World Foundation), through which the following actions } \\
\text { were taken: } \\
\text { - Homes destroyed by a hurricane were rebuilt. } \\
\text { - Inclusion initiative - opportunities for socioeconomic development were created } \\
\text { with the participation of the inhabitants of these communities as the protagonists of } \\
\text { their own social welfare projects. This helped to improve the quality of life and the } \\
\text { living conditions of the Mayan communities, while respecting and preserving the } \\
\text { local culture and environment. } \\
\text { - Initiatives for improving health - a program to combat malnutrition reduced } \\
\text { rates from 14\% in 2005 to 1.2\% in 2011. } \\
\text { Multinational chain hotel: sheets, blankets, etc., that were no longer suitable for } \\
\text { hotel use were donated to various institutions, such as those helping elderly } \\
\text { people. } \\
\text { Multinational chain hotel: donations to the Fundación Teleton (Telethon } \\
\text { Foundation), which helps to promote a culture of including people with disabilities } \\
\text { and autism in all areas of life. It also provides aid to children and young people with } \\
\text { cancer. }\end{array}$ \\
\hline $\begin{array}{l}\text { Multinational chain hotel: the employees of six hotels in Mexico raised a lot for the } \\
\text { Casa Regalo de Amor (Gift of Love House), which assists people with intellectual } \\
\text { disabilities. } \\
\text { Corporate volunteering: employees of Mexico visited the residents of the } \\
\text { Concepción Béistegui Foundation for Elderly People Private Care Institution, which } \\
\text { provides assistance to 96 senior citizens. } \\
\text { Independent hotel: inclusion - enabling cooperatives to sell products in the hotel. } \\
\text { Workshops for people in the community are integrated into cooperatives, which sell } \\
\text { their goods to the hotel, then the money remains in the area. } \\
\text { Inclusion of women - another project being carried out in the hotel involves spas. } \\
\text { "We hire women who are residents of the local communities and then train them to } \\
\text { work as therapists in spas. They are hired as cooperative workers who can then } \\
\text { offer their services in the hotel and in this way we can continue contributing to the } \\
\text { community." }\end{array}$ \\
\hline
\end{tabular}

\section{Research question 2: What are the motives for these social actions and what are their objectives? Are they proactive or reactive?}

In all the countries studied, but especially in Colombia, we found the social actions to be more reactive than proactive. Requests made by foundations and NGOs are fulfilled but on many occasions there is no clear line of action or no coordinated efforts to achieve specific objectives.

"Internally we don't have any program [of social initiatives] [...] We do nothing more than offer support to fight fires. We are reactive not proactive but we really don't have anything set up or structured."

(HR manager of a multinational chain hotel in Colombia)

Related to the foregoing, in all the countries studied, we found the initiatives to be reactive, one-off events and there were no structured programs relating to the social dimension of CSR. 
"We have not set up any social responsibility program. What we do is support the foundations that ask for aid. We provide them with linen, glassware and all tableware. Since we are a five-star hotel, we cannot use a plate with a small chip. We give away anything that can no longer be used for our services, because they have gone out of fashion [...]. We receive monthly requests, at least about two per month, but there is no established program of social responsibility. In fact, this is one of our objectives for the upcoming year."

(HR manager of a multinational chain hotel in Colombia)

Multinational chains commonly direct their efforts at the same initiative in all the member hotels worldwide (donations to UNICEF, for example). However, there are also initiatives organized separately in different hotels of the same chain that are not coordinated and that depend on the willingness of the hotel manager.

"From the standpoint of social action, the management of the hotel chain made the decision to aim its efforts toward the education of people without any means throughout the whole world. All funds are aimed in this direction to make sure they have a real impact. There are so many NGOs that, if we attempted to carry out diverse actions, the impact would be minimal [...]. In this regard, there is a long-standing initiative aimed at guests that we call Check Out for Children in which we ask customers if they would like to donate $\$ 1$ to UNICEF when checking out. In addition to this corporate program, at the local level each hotel has autonomy to do what it wants."

(CSR manager of a multinational chain hotel in Spain)

In some interviews, we found that the interviewees recognized that more could be done from the standpoint of social action and inclusion and that there was a need for such actions in Latin America.

"We had not made a commitment to implement a social responsibility program and to do so objectively. We simply consider that, if we can help all the foundations, taking into account what we have, we give a little bit to each, but we do not have any formal program."

(Manager of a multinational chain hotel in Colombia)

We also found that some hotels in Spain had taken advantage of their expertise to implement social and inclusion initiatives relating to the hotel business.

"Our social action plan envisages a program we call Up! for the People, which is divided into three parts: 1) Up! for Opportunities, 2) Up! for Hospitality, and 3) Up! for Volunteering. Within the whole framework, there is training assistance and work placements aimed at people at risk of social exclusion, in which we ask our employees to become involved. We also donate rooms for families with children who have heart disease. Another example within Up! for Volunteering is the aid that we offered to create a hotel school in Ethiopia."

(HR manager of a multinational chain hotel in Spain)

Another interesting finding was that, in Spain, there are more initiatives relating to corporate volunteering than in the other countries. We also found that there are many practices relating to the involvement of employees in social initiatives. 
"We also have social actions aimed at our employees. For example, the program Road to Awareness is aimed at responding to the concerns of those employees who want to perform actions of solidarity. This program consists of a team of employees from different hotels who take part in cycling races. People can individually sponsor one of the racers and the amounts they donate, together with the contributions of major sponsors, are allocated to the UNICEF education program."

(HR manager of a multinational chain hotel in Spain)

With regard to the issue of human rights, there was a commitment to fight prostitution and human trafficking in many of the hotels whose managers were interviewed. One interviewee stated the following:

"We have the right to refuse to provide service to certain customers and we are committed to following a global code of ethics for tourism under which, for example, we make a commitment to things like the fight against prostitution. In this way, customers also form part of our commitments and we demand certain behavior from them."

(CSR manager of a multinational chain hotel in Spain)

\section{Research question 3: Are diversity and social inclusion promoted through CSR in the hotel industry in Latin America? What impact do the social initiatives have on the local community?}

The majority of the hotels whose managers were interviewed in Colombia, Argentina and Mexico had flagship social inclusion initiatives involving the training and hiring of people from the community in which the hotel is located.

"With regard to social sustainability, unless we are unable to find people with the appropriate profile, we do not hire anyone who is not from Salta. We aim to ensure that our human resources are from the local community. In fact, when the hotel was inaugurated, we recruited and trained approximately 300 people, 120 of whom are currently employees. This was a free training program aimed at training residents of Salta in the hospitality business. Very few had experience and at the time these people were unemployed."

(HR manager of an independent hotel in Argentina)

At the same time, more than one interviewee recognized that these training and hiring actions aimed at residents of the local area are also a business need.

"Sometimes we admit that we are supporting and promoting such employment because in fact we prefer to hire people from the surrounding community. It is a double-edged sword. There is a benefit for us and for them."

(Head of human resources of a multinational chain hotel in Mexico)

A recurrent initiative (as can be seen in Table 2) in Colombia, Argentina and Mexico is the opportunity offered by some hotels for employees to complete their primary and secondary education. 
“The operational staff has a very basic level of education. In fact, some people don't even have primary education. Through the foundation, we enabled these employees to graduate. This goal was achieved through an agreement we have with the Cafam school."

(Foundation director at a multinational chain hotel in Colombia)

Additionally, inclusion is also achieved by giving job opportunities to local suppliers in the case of both large chains and small independent hotels. For example, in Argentina, one independent hotel bought its vegetables from the neighbors' gardens. Another local hotel trained and hired a person from the community to do the laundry using biodegradable products. In Colombia, one hotel explained a future project called "Patios Productivos" (Productive Courtyards), which consisted of having people in the region growing products that could be purchased by the hotel.

In regard to diversity, our findings were the same as those of De Grosbois (2012). In the CSR reports, there are few indicators of diversity management and, when such indicators exist, they are typically associated with the percentages of employees of different backgrounds, the percentage of women and men in different positions, and the number of employees who participated in diversity training. The majority of the hotels interviewed have indicated that they take into account diversity in recruitment (by not discriminating on the basis of race, sex, etc.) and also with their guests, by including different menus and respecting different cultures, etc.

Finally, it should be pointed out (as can be observed in Table 2) that, in all the Latin American countries, the hotels were found to have practices relating to health and safety: vaccination for hotel employees to prevent diseases, training on healthy nutritional practices in areas where obesity and diabetes are prominent, etc.

\section{Conclusions}

The hotel chains in the countries surveyed are aware of their social role in the development of the communities in which they operate. They also recognize that there is a need to strengthen efforts to include the disadvantaged such as low-income individuals, physically challenged individuals, young people with no training, battered women or women with few job possibilities, etc., especially in the countries studied in Latin America due to the social inequalities that exist and in Spain due to the high unemployment caused by the economic crisis prevailing since 2008.

However, although progress has been made in the areas of diversity and inclusion, many of the hotels whose managers were interviewed recognize that more and improved actions could be taken through structured plans with objectives aimed in a specific direction. In fact, we found that several hotels comply only with the minimum CSR threshold, that is, compliance with labor laws and accordingly it can be concluded that they exhibit socially irresponsible behaviors (Campbell, 2007).

Our study revealed that a significant part of the actions carried out in relation to the social dimension of CSR and more specifically to social inclusion is in response to the concerns of certain people (human resources personnel or managers) rather than a perfectly shaped policy on the actions to be undertaken. Consequently, we found that different actions had been undertaken in hotels in the same chain, depending on the geographical area in which the hotels were operated. 
As Hess (2002) stated, corporate social initiatives cannot be implemented successfully without a full understanding of the program's cost and benefits. In this sense, the empirical evidence leads us to conclude that the same is true of diversity and social inclusion initiatives. A clear policy is required in order to achieve inclusion goals. The hotel managers interviewed agree that there is a lack of coordinated actions that would enable CSR to contribute to social inclusion.

Additionally, certain initiatives among those whose aim is labor inclusion also relate to the hotels' business development needs. In some less economically developed areas, it is not easy to find people trained to work in the hotel. Therefore, the hotel has to take the initiative to train people in the community to meet its business needs. Accordingly, inclusion responds to the needs of the hotel start-up and successful business performance.

Although there are exceptions, actions carried out in relation to diversity and social inclusion are generally more reactive (sometimes arising due to legal or business needs) than proactive, that is, responsible practices adopted voluntarily (Torugsa, O’Donohue and Hecker, 2013). The proactive-reactive aspect was found to depend on local economic development and, in places with a high degree of social inequality, reactivity was found to be more prevalent than proactivity.

Most diversity initiatives were implemented in large hotel chains and therefore we can conclude that belonging to a large hotel chain was of greater importance than the country in which the interviews were conducted. Few hotel chains explained the goals of diversity management and the achievements made in this area. The hotels' CSR reports contain few indicators in this regard, and these indicators relate to the percentages of men and women in managerial positions, the total number of nationals employed, the percentage of employees with different backgrounds and the number of employees who participated in diversity training.

Although a focus on community development is considered to be of great importance in the emerging economies of the Latin American countries researched, the social dimension of CSR is still in the early stages in the Ibero-American hospitality industry and cannot be considered to be a tool of social inclusion, although some initiatives undertaken encourage such inclusion.

\section{Limitations and Future Lines of Research}

The main limitation of our study was a result of the heterogeneity of the data analyzed, which hinders the comparison between countries.

Our analysis reveals that the social context of the region in which the hotel is operated has an influence on the type of social initiatives that are undertaken. It would be interesting to do further research in this direction.

Another possible future line of research is the study of the internal corporate dimension of CSR (social initiatives), that is, centered on the social inclusion of the companies' employees. We found this area of study to be relevant and poorly developed in the current literature.

We believe that our theoretical model can serve as a starting point for future studies in this area. 


\section{References}

Barry, N.P. (2000) "Controversy: Do Corporations Have Any Responsibility Beyond Making a Profit?” Journal of Markets and Morality 3(1): 100-107.

Becchetti, L., R. Ciciretti, I. Hasan, and N. Kobeissi. (2012) "Corporate Social Responsibility and Shareholder's Value.” Journal of Business Research 65: 1628-1635.

Campbell, J. (2007) "Why Would Corporations Behave in Socially Responsible Ways? An Institutional Theory of Corporate Social Responsibility." Academy of Management Review 32 (3): 946-967.

Chiappetta, C.J., F. Serotini, J.H. Caldeira, J.C. Martínez, and R.A. Gomes (2011) "Diversity Management: Challenges, Benefits, and the Role of Human Resource Management in Brazilian Organizations." Equality, Diversity and Inclusion: An International Journal 30(1): 58-74.

Commission of the European Communities (2001) Promoting a European Framework for Corporate Social Responsibilities. COM (2001) 366 final, Brussels.

Dahlsrud, A. (2008) "How Corporate Social Responsibility Is Defined: An Analysis of 37 Definitions." Corporate Social Responsibility and Environmental Management 15(1): 1-13.

De Grosbois, D. (2012) "Corporate Social Responsibility by the Global Hotel Industry: Commitment, Initiatives and Performance." International Journal of Hospitality Management 31: 896-905.

Dreher, M.T., R.S. Machado, and A.P. Kuczmynda (2013) "Working in the Tourism Sector: Social Inclusion and Prejudices.” Cuadernos de Turismo 32: 281-294.

Elkington, J. (1998) Cannibals With Forks: The Triple Bottom Line of Sustainability. Gabriola Island, British Columbia: New Society Publishers.

Emmott, M. and D. Worman. (2008) "The Steady Rise of CSR and Diversity in the Workplace." Strategic HR Review 7(5): 28-33.

European Commission (2011) A Renewed EU Strategy 2011-14 for Corporate Social Responsibility. COM (2011) 681 final, Brussels.

Flammer, C. (2013) "Corporate Social Responsibility and Shareholder Reaction: The Environmental Awareness of Investors.” Academy of Management Journal 56: 758-781.

Friedman, M. (1970) "The Social Responsibility of Business Is to Increase its Profits." The New York Times Magazine, September 13: 122-126.

Fry, Louis W., Gerald D. Keim and Roger E. Meiners (1982) "Corporate Contributions: Altruistic or For-Profit?” Academy of Management Journal 25(1): 94-106.

Geerts, W. (2014) "Environmental Certification Schemes: Hotel Managers' Views and Perceptions." International Journal of Contemporary Hospitality Management 39: 87-96.

Goodman, N.R. (2013) “Taking Diversity and Inclusion Initiatives Global." Industrial and Commercial Training 45(3): 180-183. 
Haugh, H.M., and A. Talwar (2010). "How Do Corporations Embed Sustainability Across the Organization?” Academy of Management Learning and Education 9: 384-396.

Hess, D., N. Rogovsky, and T.W. Dunfee (2002) "The Next Wave of Corporate Community Involvement: Corporate Social Initiatives." California Management Review 44(2): 110-125.

Holcomb, J.L., R.S. Upchurch, and F. Okumus (2007) "Corporate Social Responsibility: What Are Top Hotel Companies Reporting?” International Journal of Contemporary Hospitality Management 19(6): 461-475.

Jones Christensen, L., A. Mackey, and D. Whetten (2014) "Taking Responsibility for Corporate Social Responsibility. The Role of Leaders in Creating, Implementing, Sustaining, or Avoiding Socially Responsible Firm Behaviors.” Academy of Management Perspectives 28(2): 164-178.

Jones, P., D. Hillier, and D. Comfort (2014) "Sustainability in the Global Hotel Industry." International Journal of Contemporary Hospitality Management 26(1): 5-17.

Kang, K.H., S. Lee, and C. Huh (2010) "Impacts of positive and negative CSR activities on company performance in the hospitality industry." International Journal of Hospitality Management 29(1): 72-82.

Margolis, J.D. and J.P. Walsh (2003). "Misery Loves Companies: Whither Social Initiatives by Business?” Administrative Science Quarterly 48(2): 268-305.

Navarro, Peter (1988) "Why Do Corporations Give to Charity?" Journal of Business 61(1): 65-93.

Newell, P. and J.G. Frynas (2007) "Beyond CSR? Business, Poverty and Social Justice: An Introduction.” Third World Quarterly 28(4): 669-681.

Torugsa, Nuttaneeya Ann, W. O'Donohue, and R. Hecker (2013) "Proactive CSR: An Empirical Analysis of the Role of its Economic, Social and Environmental Dimensions on the Association between Capabilities and Performance. Journal of Business Ethics 115: 383-402. 